\title{
二液分離油の反射分光摩擦面その場観察装置を用いた しゅう動部油膜その場分析
}

\author{
山田 高澄*1, 梅原 徳次 ${ }^{* 2}$, 野老山 貴行*3, 村島 基之*3 \\ 佐藤 卓 ${ }^{* 4}$ ，大原 健司 ${ }^{* 4}$, 羽生田 清志 $^{* 4}$
}

\section{In -situ analysis of two phase lubricant oil film with a reflectance spectroscopy}

\author{
Takazumi YAMADA ${ }^{* 1}$, Noritsugu UMEHARA ${ }^{* 2}$, Takayuki TOKOROYAMA*3, \\ Motoyuki MURASHIMA $^{* 3}$, Taku SATO ${ }^{* 4}$, Kenji OHARA ${ }^{* 4}$ and Kiyoshi HANYUDA ${ }^{* 4}$ \\ ${ }^{*} 1,{ }^{*},{ }^{* 3}$ Department of Mechanical Engineering, Nagoya University \\ Furo-cho, Chikusa-ku, Nagoya 464-8603, Japan \\ ${ }^{* 4}$ Shell Lubricants Japan K.K. \\ 4052-2 Nakatsu, Aikawa-machi, Aiko-gun, Kanagawa 243-0303, Japan
}

Received: 28 August 2019; Revised: 25 November 2019; Accepted: 24 March 2020

\begin{abstract}
Two phase lubricant has attracted attention as a lubricating oil with little change in viscosity with temperature change. The two phase lubricant consist of the low and high viscosity base oils which are miscible at high temperature but not at lower temperature. For exmaple, Mineral or synthetic base oil are used as a low viscosity lubricant and PAG（polyalkylene glycol） . In the high temperature region, PAG dissolves into mineral or synthetic base oil and the viscosity reduction is relieved. However, the structure and frictional characteristics of the oil film at the sliding part have not been elucidated. In this paper, in-situ analysis of the oil film formed on the friction surface was carried out with a reflection spectroscopic film thickness meter. And, this paper clarified the influence of the oil film structure and oil film thickness of the two phase lubricant and its friction characteristics. As a result, it was suggested that the oil film of the two phase lubricant in the sliding part was a multilayer due to the adsorption layer of PAG. In addition the two phase lubricant showed a friction coefficient lower by about 0.03 to 0.07 at the experimental temperature compared to PAO, and it was clarified that a thick oil film was formed.
\end{abstract}

Keywords : Two phase lubricant, Poly-a-olefin, Polyalkylene glycol, High viscosity index, Reflection spectroscopic film thickness meter

\section{1. 緒言}

現在，エンジン内部に用いられている潤滑油はベース油単体で用いられていることはなく，性能を向上させる ために様々な添加剤が用いられており, 粘度指数を向上させる添加剤としては粘度指数向上剂が用いられている. 代表的な粘度指数向上剤として，ポリメタクリレート，ポリイソブチレン，オレフィンコポリマーなどがある. これらの油溶性ポリマー分子は低温では分子鎖がコイル状に巻いたような形状をしておりべース油とほぼ变わら ない粘度を示すが，温度の上昇に伴いベース油への溶解性が上がり，分子鎖は伸びて広がった状態をとり粘度が 上昇する，そのため高温時のベース油の過度な粘度低下を抑えることができる（山本，兼田，1998）。しかし，こ の粘度指数向上剂は高分子であるため強いせん断力に弱いという欠点があり，強いせん断力が加わると分子鎖が 切断され低分子量化し，粘度が低下してしまう。そのためエンジン内のしゅう動部のように強いせん断力が加わ

No.19-00315 [DOI:10.1299/transjsme.19-00315], J-STAGE Advance Publication date : 2 April, 2020

*1 学生員, 名古屋大学 大学院工学研究科 マイクロナノ機械理工学専攻 (下464-8603 愛知県名古屋市千種区不老町)

*2 正員, フェロー, 名古屋大学 大学院工学研究科 マイクロナノ機械理工学専攻

*3 正員, 名古屋大学 大学院工学研究科 マイクロナノ機械理工学専攻

*4 シェルルブリカンツジャパン（株）（†243-0303 神奈川県愛甲郡愛川町中津 4052-2）

E-mail of corresponding author: yamada@ume.mech.nagoya-u.ac.jp 
る部分に用いられる潤滑油には粘度指数向上剤は適しておらず，粘度指数の高いベース油の開発が求められてい る（黒岩，1980）（Wong and Tung, 2016）。二液分離油は低粘度潤滑油および高粘度潤滑油の 2 種類の潤滑油を用 いることにより，潤滑油の粘度指数向上のための新しい設計手法として研究されている（Kamata et al., 2016）. この二液分離油は低粘度潤滑油として鉱油もしくは化学合成油であるポリアルファオレフィン（poly- $\alpha$-olefin, PAO), 高粘度潤滑油としてポリアルキレングリコール（polyalkylene glycol，PAG）が用いられており，低温度に おいて両潤滑油は極性および密度の違いにより分離状態で存在しているが，温度上昇に伴い PAG が PAO 内に溶 解しや寸くなるという特徴を有している（渡嘉敷，1985）（光永，1969）。高温度領域において PAG の溶解量が増 加し, 粘度の過度な低下を防ぐことにより 500 程度の粘度指数を示すことが報告されている. これは従来べース 油として使用されている潤滑油の 3 倍以上の值であることから温度依存性の低い潤滑油であると言える.

現在，二液分離油を用いた場合におけるしゅう動部の油膜構造および摩擦特性は解明されておらず，二液分離 油の適用時に最適設計を行うためには油膜構造および油膜が摩擦特性に及ぼす影響を明らかにする必要がある.

一方, 大原, 西村らによって反射分光膜厚計を用いた油中摩擦面のその場観察手法が提案されている (大原他, 2013）。この手法により摩擦材料の構造変化および構造変化した膜厚をその場観察することに成功している

(Nishimura et al., 2016)．そこでこの手法を用いることによって，しゅう動部における二液分離油の油膜構造を明 らかにできると考えた. 本研究ではしゅう動部の温度を変化させた際の摩擦係数およびしゅう動部における PAO および PAG からなる二液分離油の油膜その場分析による多層モデルを検討することで二液分離油の油膜モデル を考察した

\section{2. 実験装置および実験方法}

\section{$2 \cdot 1$ 摩擦面その場分析ピンオンディスク摩擦試験機}

潤滑油膜のその場分析は大塚電子製顕微分光膜厚計 OPTM-H2 により行った. 原理的に顕微分光膜厚計は一般 的に知られている反射分光膜厚計と同じであるため以降は反射分光膜厚計と呼称する. 反射分光膜厚計による微 小領域の絶対反射率測定により，測定試料を非接触，非破壊かつ高速に膜厚や光学定数解析が可能である．測定 された絶対反射率 $R$ は式（1）で表される.

$$
R=\frac{\text { Intensity of refrected light }}{\text { Intensity of incident light }}
$$

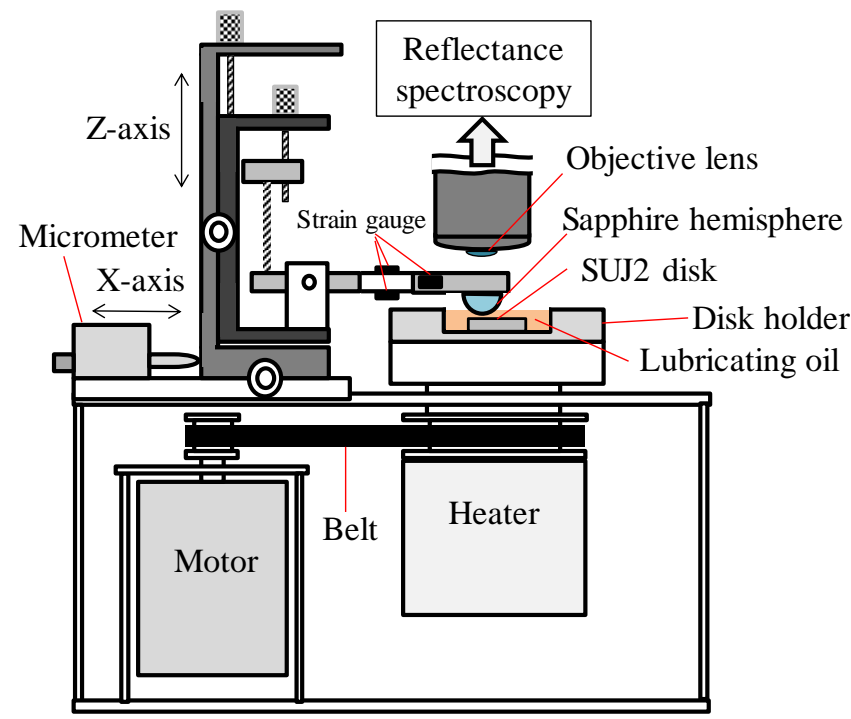

Fig. 1 In-situ pin on disk friction tester. The sliding part is installed under the optical lens of the reflection spectroscope and has a mechanism capable of optically observing the oil film through the sapphire hemisphere.

Table 1 Experimental condition of friction test.

\begin{tabular}{|c|c|c|c|}
\hline Disk & \multicolumn{3}{|c|}{ SUJ2 } \\
\hline Ball & \multicolumn{3}{|c|}{$\begin{array}{l}\text { Sapphire hemisphere } \\
(\varnothing 8 \mathrm{~mm})\end{array}$} \\
\hline Sliding speed $v, \mathrm{~m} / \mathrm{s}$ & \multicolumn{3}{|l|}{0.15} \\
\hline Normal load $W, \mathrm{~N}$ & \multicolumn{3}{|l|}{0.5} \\
\hline Sliding distance $d, \mathrm{~m}$ & \multicolumn{3}{|l|}{280} \\
\hline Temperature $T,{ }^{\circ} \mathrm{C}$ & 30 & 50 & 80 \\
\hline Lubricating oil & \multicolumn{3}{|c|}{$\begin{array}{l}\text { PAO } \\
\text { PAG } \\
\text { Two phase lubricant }\end{array}$} \\
\hline
\end{tabular}


Yamada, Umehara, Tokoroyama, Murashima, Sato, Ohara and Hanyuda,

Transactions of the JSME (in Japanese), Vol.86, No.884 (2020)

Table 2 Specimen material information. The material data of the sapphire hemisphere and SUJ2 disk were shown in the left table. The material data of the lubricating oil were shown in the right table.

\begin{tabular}{l|l|l}
\hline & $\begin{array}{l}\text { Sapphire } \\
\text { hemisphere }\end{array}$ & $\mathrm{SUJ} 2$ \\
\hline Hardness $H, \mathrm{GPa}$ & 22.5 & $6-10$ \\
\hline Young modulus $E, \mathrm{GPa}$ & 470 & 208 \\
\hline Poisson ratio $v$ & 0.27 & 0.30 \\
\hline Surface roughness $\mathrm{Rq}, \mathrm{nm}$ & $1-2$ & $8-10$ \\
\hline
\end{tabular}

\begin{tabular}{l|l|l|l}
\hline \multicolumn{2}{l|}{ Lubricating oil } & PAO & PAG \\
\hline \multirow{4}{*}{ Viscosity $\eta, \mathrm{mPa} \cdot \mathrm{s}$} & $30^{\circ} \mathrm{C}$ & 17.9 & 861 \\
\cline { 2 - 4 } & $50^{\circ} \mathrm{C}$ & 8.42 & 343 \\
\cline { 2 - 4 } & $80^{\circ} \mathrm{C}$ & 3.75 & 32 \\
\hline \multirow{3}{*}{$\begin{array}{l}\text { Pressure-viscosity } \\
\text { coefficient } \alpha, \mathrm{GPa}^{-1}\end{array}$} & $30^{\circ} \mathrm{C}$ & 19 & 32 \\
\cline { 2 - 4 } & $50^{\circ} \mathrm{C}$ & 14 & 24 \\
\cline { 2 - 4 } & $80^{\circ} \mathrm{C}$ & 11 & 18 \\
\hline
\end{tabular}

摩擦試験機のしゅう動部は反射分光膜厚計に設置されている反射光を入射する光学レンズ直下に設置され, サ ファイア半球を通して摩擦面に形成された油膜を光学的に観察できる機構を有している. 用いたサファイア半球 は入射光の波長が 300 - $800 \mathrm{~nm}$ の可視光領域において透過性が $85 \%$ 以上である. 荷重は Z 軸を上下させることに より与え，接触点の回転半径はマイクロメーターを用いてX軸を調整することによって設定した. 荷重および摩 擦力は, 平行板バネに貼り付けたひずみゲージにより測定した. 装置の模式図を図 1 に示し, 本研究における摩 擦試験条件を表 1 に示す．また，実験に用いた試験片および潤滑油に関する材料データを表 2 に示す．粘度の圧 力係数 を算出する際に使用した式を以下に示す. 式 (2) に Waltherの式を示し, 式 (3) に Wu-Klaus-Duda の式 を示した. A及びmは材料固有の定数である. $30^{\circ} \mathrm{C}$ 及び $80^{\circ} \mathrm{C}$ における潤滑油の温度 $T$ 及び動粘度 $v$ を式 (2) に代 入し連立方程式を解き，式（3）に代入することにより $\alpha$ 算出した（Wu et al., 1989）.

$$
\begin{aligned}
& \log _{10} \log _{10}(v+0.7)=\mathrm{A}-\mathrm{m} \log _{10} T \\
& \alpha=\left(0.1657+0.2332 \log _{10} v\right) \times \mathrm{m} \times 10^{-8}
\end{aligned}
$$

\section{$2 \cdot 2$ 分光エリプソメータによる光学定数測定および反射分光膜厚計による膜厚分析}

油膜のような薄膜の厚さおよび光学定数を測定するために入射光の薄膜内多重反射を考慮した光学モデルが 必要となり，その光学モデルから反射率を算出する（藤原，2011）（Collins et al., 1998）. 基板上に厚さ $t_{1}$ の薄膜か らなるモデルの模式図を図 2 に示寸. 媒質中で 1 層の薄膜に光が入射角 $\theta_{0}$ で入射した時の反射率 $R$ を以下の式に 示す. 以下の式において, $i$ は虚数を示す.

$$
\begin{aligned}
& R=\left|\frac{r_{01}+r_{12} \exp (-2 \beta i)}{1+r_{01} r_{12} \exp (-2 \beta i)}\right|^{2} \\
& N_{m}=n_{m}-i k_{m} \quad\left(\mathrm{~m}=0,1,2, N_{m}, n_{m} \text { および } k_{m} \text { は波長 } \lambda \text { の関数 }\right) \\
& r_{a b}=\frac{N_{a} \cos \theta_{a}-N_{b} \cos \theta_{b}}{N_{a} \cos \theta_{a}+N_{b} \cos \theta_{b}} \quad(\mathrm{a}=0,1, \mathrm{~b}=1,2) \\
& \beta=\frac{2 \pi t_{1} N_{1} \cos \theta_{1}}{\lambda}
\end{aligned}
$$

ここで $R$ は反射率， $t_{1}$ は薄膜の厚さ， $\lambda$ は光の波長， $n$ は屈折率， $k$ は消衰係数を表す．雰囲気層，薄膜層およ び基板層の 3 層におけるそれぞれの界面からの振幅反射率をそれぞれ $r_{01}$ および $r_{12}$ とする．添え字 $0,1,2$ はそ れぞれ空気, 薄膜, 基板を表す，実際に潤滑油を用いた際の光学モデルは図 3 に示すように雰囲気層にサファイ 
Yamada, Umehara, Tokoroyama, Murashima, Sato, Ohara and Hanyuda,

Transactions of the JSME (in Japanese), Vol.86, No.884 (2020)

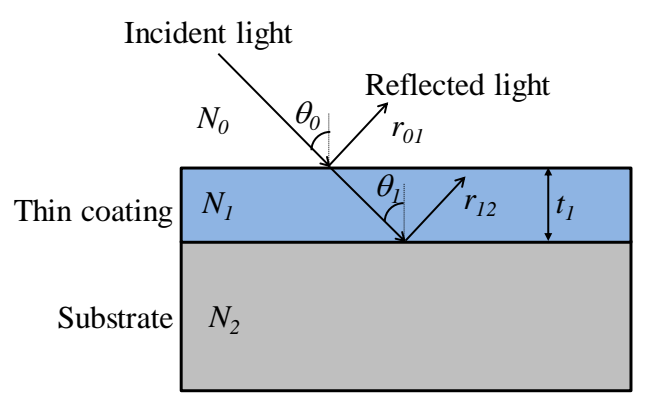

Fig.2 Schematic diagram of thin film with thickness $t_{l}$ formed on substrate. It shows reflectance $R$ when incident on thin film at incident angle $\theta_{0}$.

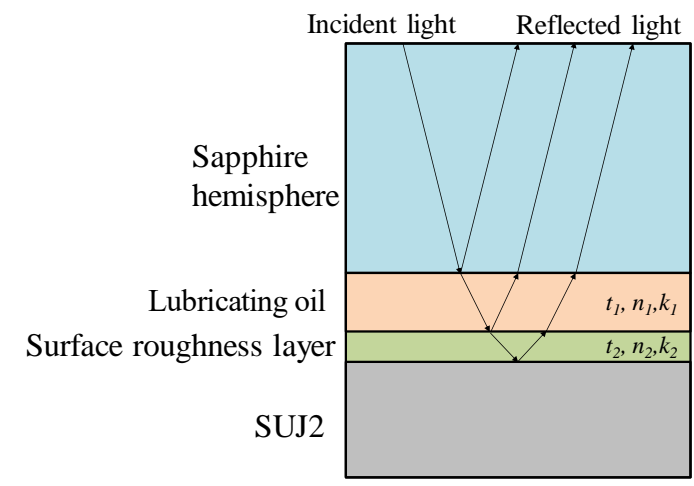

Fig.3 Schematic diagram of optical model in case of using lubricating oil. Subscripts 0, 1, 2 and 3 represent sapphire hemisphere, lubricating oil, surface roughness layer and SUJ 2 respectively.

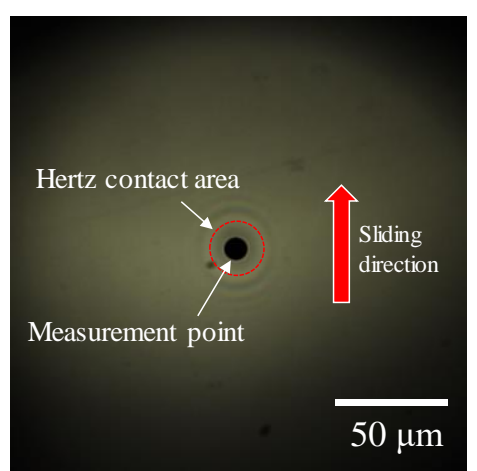

Fig. 4 The CCD image of contact point in friction test was shown in this figure. The black circle showed the measurement spot of the reflectance spectroscopy. The red circle showed the hertz contact area in the case of this experimental condition.

ア，その下に油膜，表面粗さ層，基板層に SUJ2 とした．この光学モデルから計算される反射率 $R$ は以下の式で 表される.

$$
\begin{aligned}
& R=\left|\begin{array}{lcc}
r_{01}+r_{12}\left(-2 \beta_{1} i\right)+\left[r_{01} r_{12}+\exp \right. & \left.\left(-2 \beta_{1} i\right)\right] r_{23} \exp & \left(-2 \beta_{2} i\right) \\
\hline 1+r_{01} r_{12}\left(-2 \beta_{1 i}\right)+\left[r_{12}+r_{01} \exp \right. & \left.\left(-2 \beta_{1} i\right)\right] r_{23} \exp & \left(-2 \beta_{2} i\right)
\end{array}\right|^{2} \\
& N_{m}=n_{m}-i k_{m} \quad\left(\mathrm{~m}=0,1,2,3, N_{m}, n_{m} \text { および } k_{m} \text { は波長 } \lambda \text { の関数 }\right) \\
& r_{a b}=\frac{N_{a} \cos \theta_{a}-N_{b} \cos \theta_{b}}{N_{a} \cos \theta_{a}+N_{b} \cos \theta_{b}} \quad(\mathrm{a}=01,2, \mathrm{~b}=1,2,3) \\
& \beta_{m}=\frac{2 \pi t_{m} N_{m} \cos \theta_{m}}{\lambda}
\end{aligned}
$$

添え字 0，1，2，3 はそれぞれサファイア，油膜，表面粗さ層，SUJ2 を表す，そして，式（1）の反射率のスペ クトルに式 (8) で計算された反射率スペクトルについて非線形最小二乗法を用いてフィッティングすることによ り薄膜の厚さおよび光学定数が求まる. また, 図 4 に測定時の摩擦面画像を示す. サファイア半球と SUJ2 基板 
のヘルツ接触直径は $24 \mu \mathrm{m}$ であり, これは反射分光膜厚計による測定スポット径 $10 \mu \mathrm{m}$ の 2 倍以上あるため, 測定された反射率スペクトルは接触面における值を表していると考えられる．最後に，本実験では使用する潤滑 油の光学定数（屈折率 $n$ および消衰係数 $k$ ）は事前に分光エリプソメータ（大塚電子製，FE-5000）を用いて測定 を行っている. そのためその場分析を行う際に光学定数は既知の定数として扱うことができ，油膜厚さ $t$ のみを 変数として算出可能としている. また，表面粗さ層については 3.2 節で説明する.

\section{$2 \cdot 3$ 実験に用いた潤滑油}

本実験で用いた潤滑油はベース油として多く用いられている PAO, PAG および二液分離油 (Two phase lubricant) としてPAGとPAO の混合比を 1:4 とした潤滑油を用いた.

\section{3. 油膜その場分析の妥当性および二液分離油の油膜モデルの検討}

\section{$3 \cdot 1$ 油膜その場分析の妥当性の検討}

表 1 に示した実験条件において, 摩擦面における油膜その場分析をPAO 単体および PAG 単体を用いて行い, しゅう動部における油膜厚さを測定した．そして算出した点接触下における理論油膜厚さと比較することで反射 分光膜厚計を用いた油膜その場分析の妥当性を検討した．また，点接触下における接触中央部膜厚を弾性流体理 論により算出した（山本，兼田，1998）。以下に本実験条件である点接触下における理論油膜厚さ $h$ の計算式を 示す. 本実験環境は高圧粘度-弾性体領域の潤滑状態として計算を行い, 計算に用いた材料パラメータは表 2 に示 したものを使用した.

$$
\begin{aligned}
& \frac{h}{R_{x}}=3.68\left(\frac{\eta_{0} u}{E R_{x}}\right)^{0.68} \cdot(\alpha E)^{0.49} \cdot\left(\frac{w}{E R_{x}^{2}}\right)^{-0.073}\left[1-\exp \left\{-0.67\left(\frac{R_{y}}{R_{x}}\right)^{\frac{2}{3}}\right\}\right] \\
& \frac{1}{E}=\frac{1-\nu_{1}^{2}}{E_{1}}+\frac{1-\nu_{2}^{2}}{E_{2}}
\end{aligned}
$$

$R_{x}$ およ゙ $R_{y}$ はそれぞれ $\mathrm{X}$ 軸および $\mathrm{Y}$ 軸を含めた面内での等価半径, 引き込み速度 $u$ とする. ここで各面の速 度を $u_{1}, u_{2}$ とすると，引き込み速度は $u=\left(u_{1}+u_{2}\right) \quad / 2$ で示される. 本実験では $u_{2}=0$ とする. $\eta_{0}$ は大気圧下で の粘度， $\alpha$ は粘度の圧力係数， $w$ は荷重， $E$ は等価弾性係数を表しており， $E_{1}$ おび $E_{2}$ はそれぞれの面における弾 性係数である. $\nu_{1} お よ ひ ゙ \nu_{2}$ はそれぞれの面におけるポアソン比である. 式（12）に代入することにより理論油膜
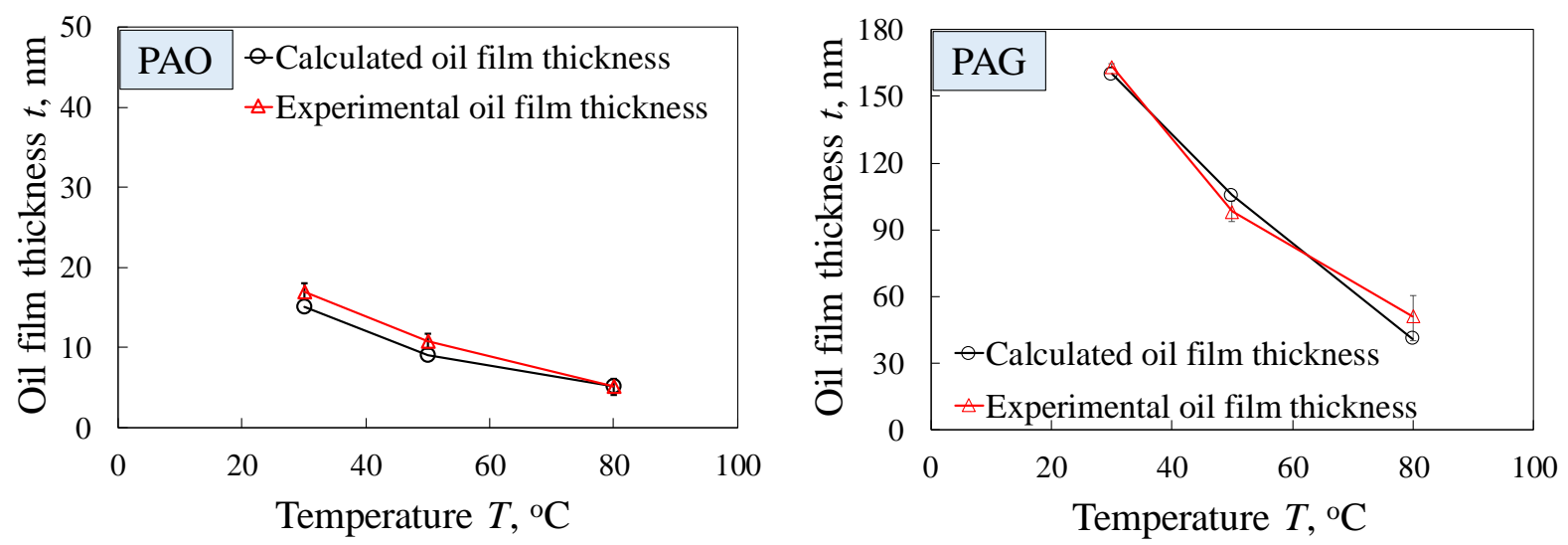

Fig. 5 Comparison between experimental oil thickness and calculated oil thickness. The left graph showed the result in using PAO and the right graph showed the result in using PAG. In both graphs, comparing the calculated oil film thickness with the oil film thickness measured using the in-site analysis, experiments resulted in the same tendency of oil film thickness to decrease. 
厚さを求めた．図 5 に 30,50 および $80^{\circ} \mathrm{C}$ にける油膜のその場分析結果および弾性流体理論を用いた理論油膜 厚さの計算結果を示す.

表 1 に示した実験条件を用いた摩擦試験における油膜のその場分析結果と実験条件の值を用いて算出した理論 油膜厚さを比較すると, PAO および PAG を用いた両方の実験において温度上昇に伴い油膜厚さが減少するとい う傾向が一致し, 各温度の油膜厚さの誤差が平均して約 $3 \mathrm{~nm}$ 程度という精度で油膜厚さが測定できることが示 された．また，本実験でフィッティングに用いた PAO およびPAG 光学定数の測定值およびフィッティングにお いて得られた結果を図 6 に示す。本実験では，潤滑油のフィッティングにおいて一般的に透明材料に用いられる Cauchy のモデル式を用いた，モデル式を式（14）および式（15）に示し，各実験温度における PAO および PAG のフィッティングにより得られた定数を表 3 に示す. PAO および PAG の光学定数の測定值とよく一致すること が示された。

$$
\begin{aligned}
& n(\lambda)=\frac{a_{1}}{\lambda^{4}}+\frac{a_{2}}{\lambda^{2}}+a_{3} \\
& k(\lambda)=\frac{b_{1}}{\lambda^{4}}+\frac{b_{2}}{\lambda^{2}}+b_{3}
\end{aligned}
$$

\section{$3 \cdot 2$ 油膜その場分析に用いた二液分離油の光学モデル}

反射分光膜厚計で油膜その場分析に用いる二液分離油の光学モデルとして仮説を三つ検討した。一つはしゅう 動部においてPAO 内にPAG が溶解しており単一の潤滑油による油膜が形成されているモデルである. 概念図を 図 7 に示す.この光学モデルを立てる上で用いたのが異種物質の体積割合を薄膜の光学定数から求める有効媒質 近似法である（Koh et al., 1996）。今回は異種物質の体積割合を決定することによってPAO 内に PAG が溶解した 状態の光学定数を算出することができる. 油膜が複数の異種物質で構成された膜と仮定することで，油膜内に存 在する異種物質の体積割合と光学定数の関係が以下の式のように表される.ここで， $f_{s}$ とをはそれぞれ薄膜内の異 種物質の体積割合と誘電率であり， $n_{\text {oil }}$ は屈折率， $k_{\text {oil }}$ は消衰係数である. また $N_{\text {oil }}$ は複素屈折率を表す.

$$
\begin{aligned}
& f_{s} \frac{\varepsilon_{P A O}-\varepsilon}{\varepsilon_{P A O}+2 \varepsilon}+\left(1-f_{s}\right) \frac{\varepsilon_{P A G}-\varepsilon}{\varepsilon_{P A G}+2 \varepsilon}=0 \\
& \varepsilon_{o i l}=N_{o i l}^{2}=\left(n_{o i l}^{2}-{k_{o i l}}^{2}\right)-i\left(2 n_{\text {oil }} k_{o i l}\right)
\end{aligned}
$$

また，本実験で用いた表面粗さ層においてもこの手法を利用し，SUJ2 の表面粗さと潤滑油が混在する層を，表 面粗さ層としている. Joohyun Koh は有効媒質近似より評価した表面粗さ層厚さ $t_{s}$ は原子間力顕微鏡から評価さ れる二乗平均平方根粗さ $R \mathrm{q}$ と非常によく一致し，以下の関係があると報告している（Koh et al., 1996）.この表面 粗さ層の膜厚は式 (18) に示すように表面粗さに依存しており, 表面粗さが実験前後で変化がなかったことから, 本実験条件では $15.4 \mathrm{~nm}$ と固定して計算している.

$$
t_{s}=1.5 R q+0.4
$$

二つ目に提案するモデルは図 8 に示すように，密度の違いによって上層に PAO, 下層にPAG の二層に分離し て油膜が形成されるとしたモデルである. 
最後に二液分離油に用いられている PAO およびPAG の分子構造の違いに着目したモデルを考案した. PAO の 構造式を図 9 に示し，PAG の構造式を図 10 に示寸，PAO はエチレンから生成される $\alpha$-オレフィンを重合させる ことで化学的に合成される合成炭化水素である. それに対し，PAG はエチレンオキサイドおよびプロピレンオキ サイド等のアルキレンオキサイドの付加重合によって得られるオリゴマーであり, 分子構造内に酸素原子を含み, また末端に水酸基を有している．分子構造内の酸素原子の存在により電子密度の偏りが生じ極性のある分子とな っており，分子間力により凝集力が大きい，そして末端にある水酸基により反応性が高いためしゅう動部におい ては表面へ化学吸着が生じやすい（今村，1965）（鈴木，近藤，1996）．以上の PAO および PAG の吸着力の違い に着目し，しゅう動部に形成される $\mathrm{nm}$ サイズの油膜は PAG が摩擦試験機のボール側であるサファイア半球およ びディスク側である SUJ2 に吸着し層を生成する層状の構造になっていると考え, 図 11 に示した油膜構造モデル および光学定数測定に用いる光学モデルを考案した.

Table 3 The constants of the Cauchy model.

\begin{tabular}{|c|c|c|c|c|c|c|c|}
\hline & & \multicolumn{3}{|c|}{ PAO } & \multicolumn{3}{|c|}{ PAG } \\
\hline & & $30^{\circ} \mathrm{C}$ & $50^{\circ} \mathrm{C}$ & $80^{\circ} \mathrm{C}$ & $30^{\circ} \mathrm{C}$ & $50^{\circ} \mathrm{C}$ & $80^{\circ} \mathrm{C}$ \\
\hline \multirow{3}{*}{ Reflective index $n$} & $\mathrm{a}_{1}$ & $1.08 \times 10^{8}$ & $8.52 \times 10^{7}$ & $1.54 \times 10^{7}$ & $1.17 \times 10^{8}$ & $1.12 \times 10^{8}$ & $8.54 \times 10^{7}$ \\
\hline & $\mathrm{a}_{2}$ & $3.09 \times 10^{3}$ & $3.69 \times 10^{3}$ & $4.66 \times 10^{3}$ & $3.19 \times 10^{3}$ & $3.19 \times 10^{3}$ & $3.46 \times 10^{3}$ \\
\hline & $\mathrm{a}_{3}$ & 1.45 & 1.44 & 1.43 & 1.44 & 1.43 & 1.42 \\
\hline \multirow{3}{*}{ Extinction coefficient $k$} & $\mathrm{~b}_{1}$ & $-7.48 \times 108$ & $-6.66 \times 10^{8}$ & $-6.54 \times 10^{8}$ & $-1.14 \times 10^{9}$ & $-9.64 \times 10^{8}$ & $-6.54 \times 10^{8}$ \\
\hline & $\mathrm{b}_{2}$ & $1.28 \times 10^{4}$ & $8.30 \times 10^{3}$ & $6.91 \times 10^{3}$ & $1.38 \times 10^{4}$ & $1.17 \times 10^{4}$ & $6.91 \times 10^{3}$ \\
\hline & $b_{3}$ & $1.88 \times 10^{-2}$ & $2.87 \times 10^{-2}$ & $3.06 \times 10^{-2}$ & $2.74 \times 10^{-2}$ & $2.55 \times 10^{-2}$ & $3.06 \times 10^{-2}$ \\
\hline
\end{tabular}
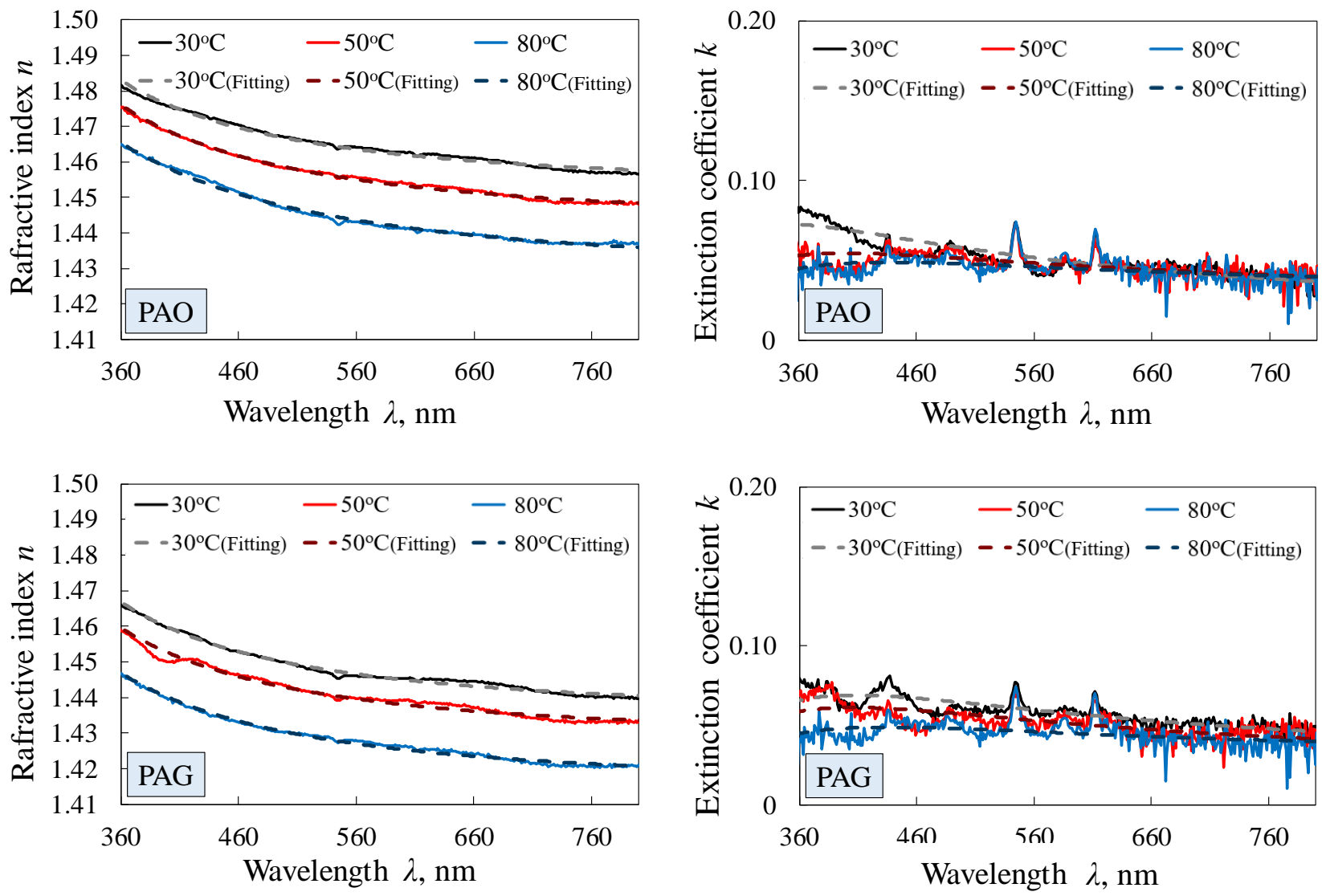

Fig. 6 The optical constants $n$ and $k$ of PAO and PAG in this experiment. The solid line shows the measured value, and the dotted line shows the fitting result with the n-k Cauchy model. 
Yamada, Umehara, Tokoroyama, Murashima, Sato, Ohara and Hanyuda,

Transactions of the JSME (in Japanese), Vol.86, No.884 (2020)

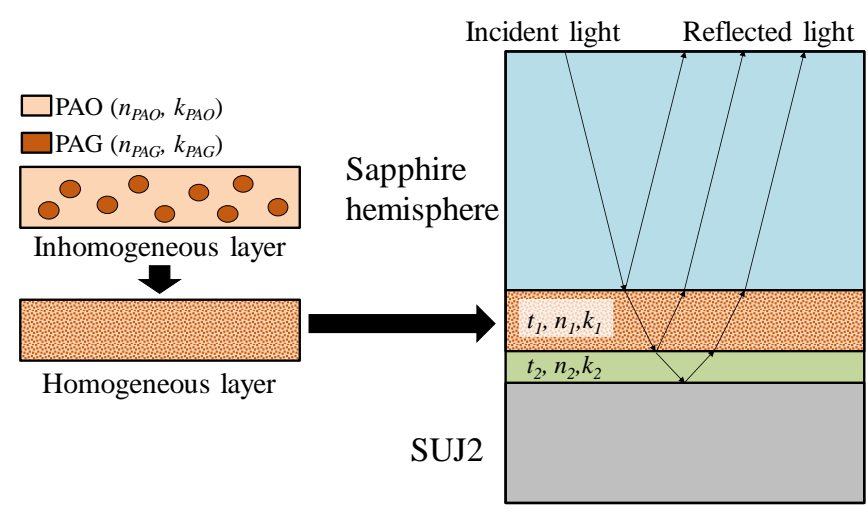

Fig. 7 The optical model of two phase lubricant in case of mixing model. PAO and PAG are mixed in the sliding part, so oil film is formed as homogeneous layer. The left figure shows lubricating oil which PAO and PAG are completely mixed. The right figure shows the optical model using the mixed oil.

$$
\left\{\begin{array}{l}
\mathrm{C}_{8} \mathrm{H}_{17} \\
\mathrm{CH}-\mathrm{CH}_{2}
\end{array}\right]_{\mathrm{n}}
$$

Fig. 9 The structural formula of PAO. It has a linear structure of carbon.<smiles>CCCCOC(C)(C)C(C)(C)CC(C)OC</smiles>

Fig. 10 The structural formula of PAG. Oxygen atoms and functional groups are present in the molecule.

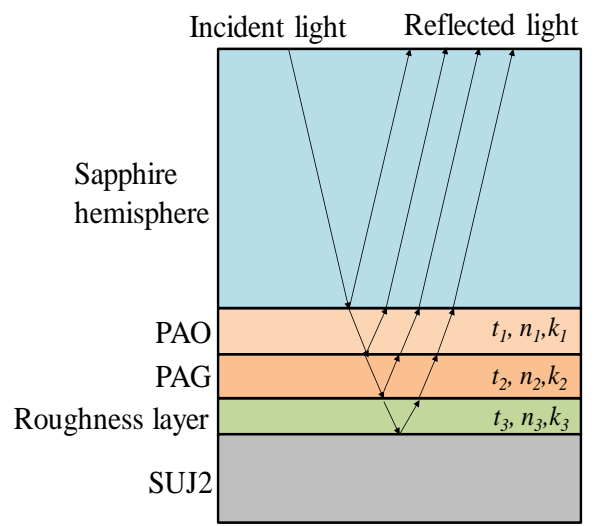

Fig. 8 The optical model of two phase lubricant in case of two-layer model. It is a model in which an oil film is formed two-layer by separating due to the difference in density.

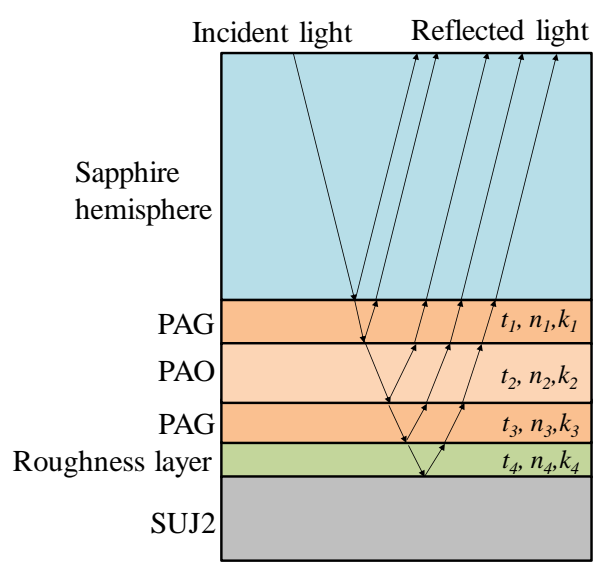

Fig.11 The optical model of two phase lubricant in case of three-layer model. We made a model focusing on the difference in molecular structure between PAO and PAG.

以上の光学モデルを用いて算出した反射率と反射分光膜厚計から得られた摩擦面の反射率にフィッティングを 行うことにより光学モデルの各層における最適な膜厚を求めた. その際に精度良くフィッティングを行うことが できた光学モデルの構造で油膜が形成されていることが推定できる.

\section{4. 混合比の異なる二液分離油を用いた摩擦試験結果およびその場油膜分析結果}

表 1 に示した実験条件において，二液分離油 PAO 単体および PAG 単体を用いた摩擦試験を行った。これらの 試験油を用いた実験では，すべり距離が $d=200-250 \mathrm{~m}$ における平均摩擦係数および反射分光膜厚計を用いた油 膜のその場分析を行い，二液分離油については測定された反射率に三つの光学モデルを用いてフィッティングを 行った. 各光学モデルおよび各温度におけるフィッティング結果を表 4 に示す. 光学モデルの精度の高さを表す 值Fは以下の式を用いて算出される.

$$
S=\sum_{j=1}^{m}\left\{\left(Y_{j}-Y_{j}^{\prime}\right)^{2}\right\}
$$


Yamada, Umehara, Tokoroyama, Murashima, Sato, Ohara and Hanyuda,

Transactions of the JSME (in Japanese), Vol.86, No.884 (2020)

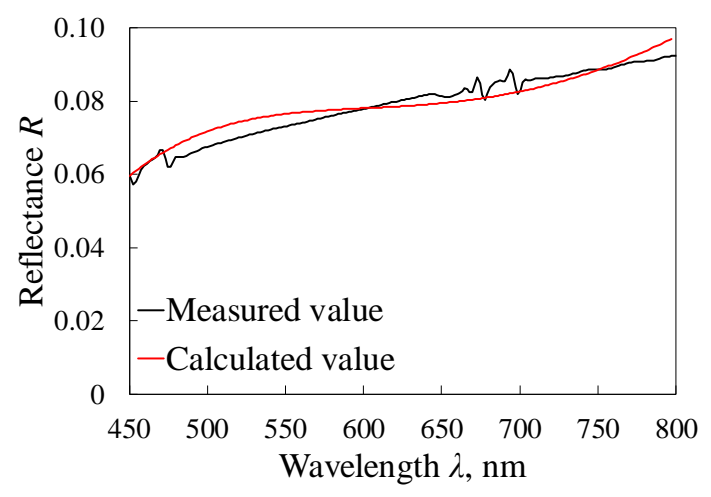

Fig. 12 The comparison of measured reflectance by a reflectance spectroscopy and reflectance spectrum calculated from the optical model of mixing model $\left(30^{\circ} \mathrm{C}\right)$.

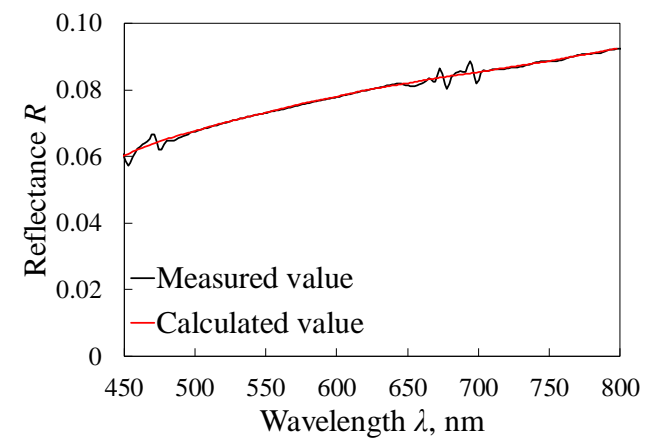

Fig. 14 The Comparison of measured reflectance by a reflectance spectroscopy and reflectance spectrum calculated from the optical model of three-layer model $\left(30^{\circ} \mathrm{C}\right)$.

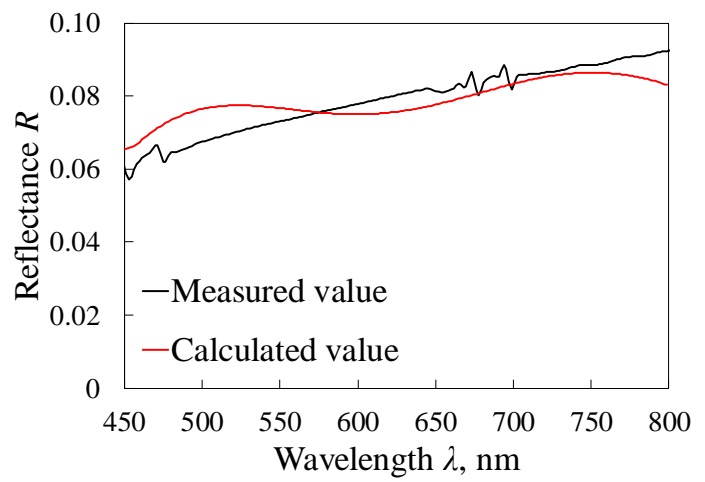

Fig. 13 The comparison of measured reflectance by a reflectance spectroscopy and reflectance spectrum calculated from the optical model of two-layer model $\left(30^{\circ} \mathrm{C}\right)$.

Table 4 Fitting accuracy.

\begin{tabular}{c|c|c|c}
\hline \multirow{2}{*}{$\begin{array}{c}\text { Temperature } \\
T,{ }^{\circ} \mathrm{C}\end{array}$} & \multicolumn{3}{|c}{ Fitting accuracy, \% } \\
\cline { 2 - 4 } & Mixing & Two-layer & Three-layer \\
\hline 30 & 35 & 15 & 95 \\
50 & 25 & 21 & 94 \\
80 & 31 & 20 & 96 \\
\hline
\end{tabular}

$$
F=\left(1-\frac{\sqrt{\frac{S}{m}}}{\sigma}\right) \times 100
$$

$S$ は二乗残差和， $Y_{j}$ は測定された反射率であり， $Y_{j}^{\prime}$ は光学モデルから算出された反射率である. 光学モデルの精度 の高さを表す值 $F$ は二乗残差和 $S$, データ数 $m$ および測定された反射率の母集団の標準偏差 $\sigma$ を用いて算出した. また PAO 単体および PAG 単体を用いた実験では, 図 3 に示した油膜層が一層の光学モデルを用いてフィッティ ングを行い，油膜厚さを測定した。

図 12, 13 および 14 に実験温度 $30^{\circ} \mathrm{C}$ において反射分光膜厚計で測定した反射率の測定結果を示寸. 加えて, 3.2 節で示した 3 つのモデルを用いてフィッティングを行った結果を表 4 に示した. 以上より PAG の吸着層が SUJ2 およびサファイア半球表面に存在する 3 層の光学モデルがより精度が高いということが示された. また表 4 に示すように全実験温度において，光学モデルから算出される反射率をより実際に測定された反射率にフィッテ イングを行うことができたのはPAG の吸着層が存在する三層モデルであった. そのため, 本実験条件においてし ゆう動部における二液分離油は PAG の吸着層の存在により多層化した油膜を形成していることが推測された. ここで, PAG の吸着層が存在している 3 層の光学モデルを立てる際に，油膜構造として PAG にのみ官能基があ ることから，優先的に摩擦表面に物理吸着するため摩擦面に存在していると考えている．そこでより精度の高い フィッティングを行うために吸着層において PAG 単体ではなく, 実際は PAO が混入していることが予想される ため，今後は PAG に少量の PAO が混入したモデルを構築する必要があると考える. 二液分離油の平均摩擦係数 
Yamada, Umehara, Tokoroyama, Murashima, Sato, Ohara and Hanyuda,

Transactions of the JSME (in Japanese), Vol.86, No.884 (2020)

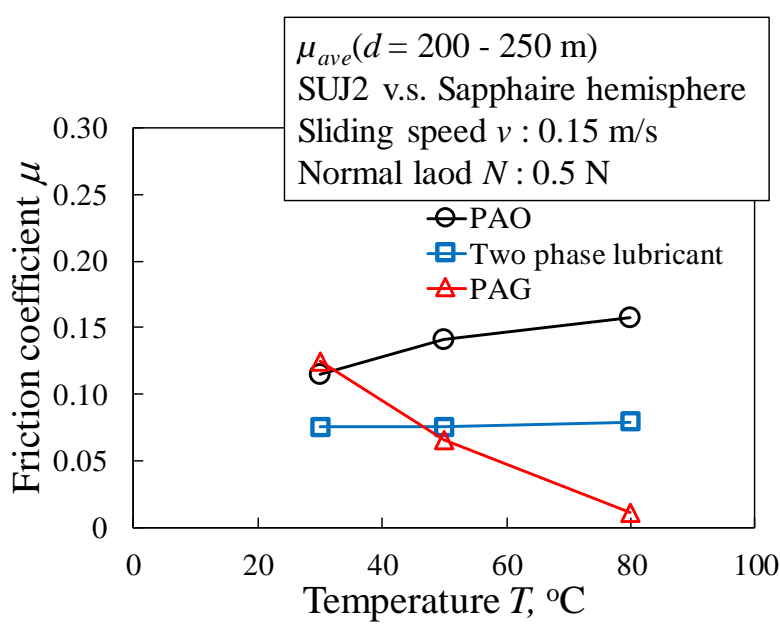

Fig.15 The average friction coefficient of PAO, PAG and two phase lubricant in sliding distance 200 250 $\mathrm{m}$. The average friction coefficient of two phase lubricant was constant at a value of about 0.07 at each temperature.

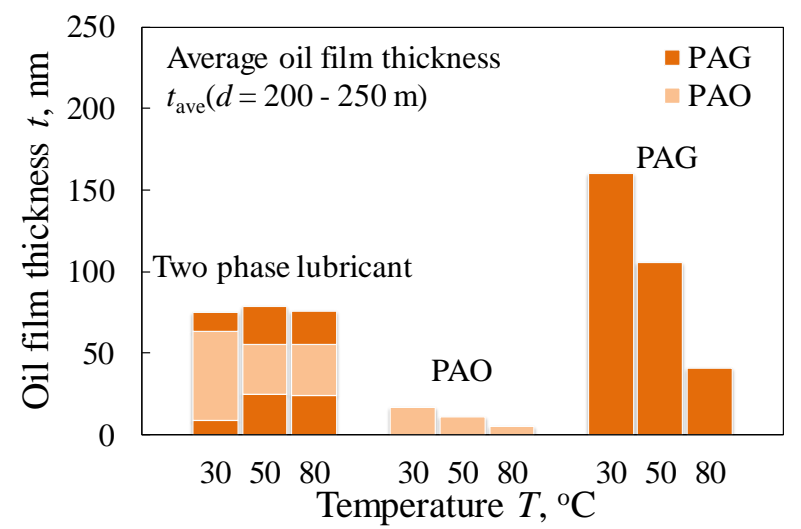

Fig.16 The average oil thickness of PAO, PAG and two phase lubricant in sliding distance $200 \sim 250 \mathrm{~m}$. In the case of two phase lubricant, it was revealed that the total oil film thickness was constant at about $70 \mathrm{~nm}$ at each temperature.

は図 15 に示すように, $30^{\circ} \mathrm{C}, 50^{\circ} \mathrm{C}$ および $80^{\circ} \mathrm{C}$ の各温度において平均摩擦係数が 0.07 程度の值で一定であった. また, 摩擦面その場分析による油膜厚さ分析結果を図 16 に示す.三層の油膜厚さの合計油膜厚さは各温度におい て $70 \mathrm{~nm}$ 程度と一定であることが明らかとなった.

次に PAO 単体を用いた場合における平均摩擦係数の結果より， $30^{\circ} \mathrm{C}$ における平均摩擦係数は $0.11,50^{\circ} \mathrm{C}$ にお いては $0.14,80^{\circ} \mathrm{C}$ においては 0.16 と温度の上昇に伴い平均摩擦係数が上昇していることが示された. 次にその場

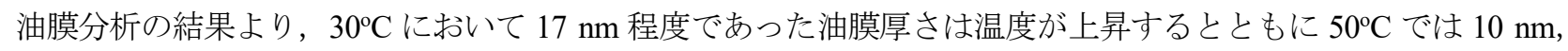
$80^{\circ} \mathrm{C}$ では $5 \mathrm{~nm}$ と減少することが示された.

最後に PAG 単体を用いた場合における平均摩擦係数の結果より, $30^{\circ} \mathrm{C}$ における平均摩擦係数は $0.12,50^{\circ} \mathrm{C}$ に おいては $0.066,80^{\circ} \mathrm{C}$ においては 0.011 と温度の上昇に伴い平均摩擦係数が減少していることが示された. 次にそ

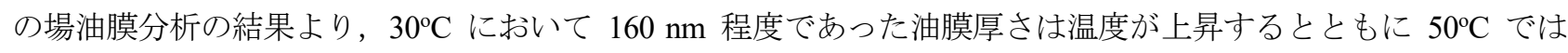
$105 \mathrm{~nm}, 80^{\circ} \mathrm{C}$ では $41 \mathrm{~nm}$ と減少することが示された.

\section{5. 考察}

\section{$5 \cdot 1$ 二液分離油の油膜厚さが摩擦特性に及ほす影響}

二液分離油の摩擦係数の変化を考察するために, PAO 単体, PAG 単体および二液分離油の粘度を室温 $\left(23^{\circ} \mathrm{C}\right)$ から $80^{\circ} \mathrm{C}$ において測定した. 図 15 に PAO 単体, PAG 単体および二液分離油の粘度測定結果を示す。この結果 より $\mathrm{PAO}$ 単体および PAG 単体は温度上昇に伴い粘度が低下しており, 二液分離油は温度が上昇すると $\mathrm{PAG}$ の溶 解により粘度が大きく低下しなかった。 そこで，この結果より潤滑油の粘度から各温度の潤滑状態に関しては， 潤滑下における突起間干渉の程度を与えるパラメータである膜厚比 $\Lambda$ を用いて検討した. ここで膜厚比は式(21) で計算し，式（21）における $t$ は油膜厚さ， $\sigma$ は摩擦面における両面の合成粗さを表す.

$$
\Lambda=\frac{t}{\sigma}
$$

図 18 に各潤滑油における膜厚比と平均摩擦係数の関係を示した. $\mathrm{PAO}$ 中は $30^{\circ} \mathrm{C}$ においては $1<\Lambda<3$ であるた め混合潤滑状態であり， 50 および $80^{\circ} \mathrm{C}$ においては $\Lambda<1$ であるため境界潤滑状態であることが示唆された，その ため PAO 中では混合潤滑状態から境界潤滑状態であることから温度上昇に伴い油膜厚さが表面粗さより小さく 
Yamada, Umehara, Tokoroyama, Murashima, Sato, Ohara and Hanyuda,

Transactions of the JSME (in Japanese), Vol.86, No.884 (2020)

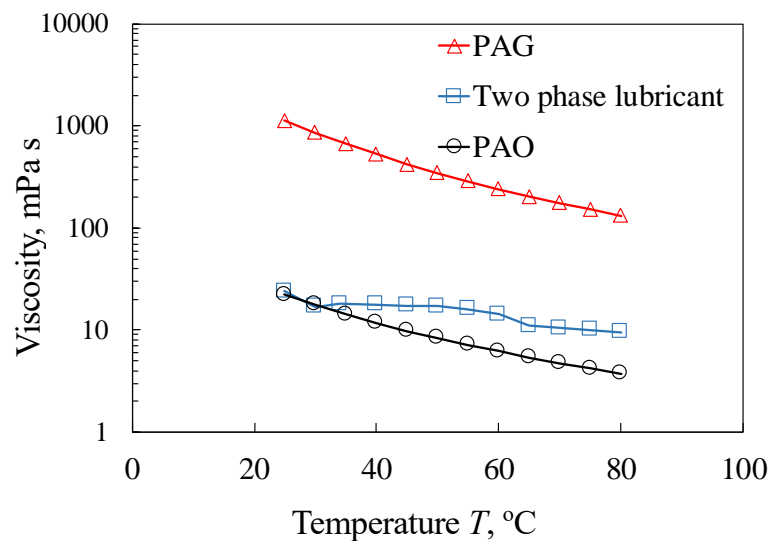

Fig. 17 Viscosity of PAO, PAG and two phase lubricant. This graph shows that the viscosity of two phase lubricant doesn't decrease in high temperature.

なり，しゅう動部における接触により摩擦係数が上昇したと考える．また PAG 中の場合，全実験温度において 3 <イであることが示されており，表面接触頻度の少ない流体潤滑状態であることが考えられる，そのため，温度 上昇に伴い粘度が低下したことのより，粘性抵抗が減少し，摩擦係数が低下したことが考えられる．ここで二液 分離油の粘度を用いて算出した油膜厚さの場合, 温度上昇に伴い潤滑状態は混合潤滑から境界潤滑となるため, 表面突起の接触頻度が上昇し, 摩擦係数は上昇することが考えられる. しかし, 図 15 の結果より二液分離油の摩 擦係数は一定となり, PAO 中の平均摩擦係数と比較しても低い值を示しているため, 粘度から算出した油膜厚さ だけでは二液分離油の摩擦特性を説明することができない，そのため，油膜構造を含めた考察が必要であるとい う考察に至った.

そこで二液分離油の摩擦特性を反射分光膜厚計で分析した油膜構造及び油膜厚さから考察した. 反射分光膜厚 計から求めた油膜厚さを用いて膜厚比 $\Lambda$ を算出し，二液分離油の各層の油膜厚さを合計した見かけの油膜厚さが 平均摩擦係数へ及ぼす影響を考察した. 図 18 に二液分離油の膜厚比 $\Lambda$ と平均摩擦係数の関係を示す.この時二液

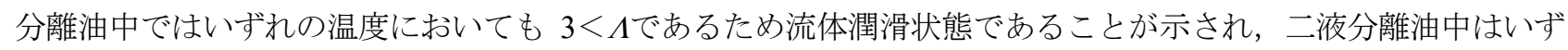
れの混合比でもしゅう動部における接触頻度の少ない流体潤滑状態であり, 温度上昇に伴い油膜厚さが減少しな かったことにより摩擦係数が 0.07 程度と低い值を維持したのではないかと考える.
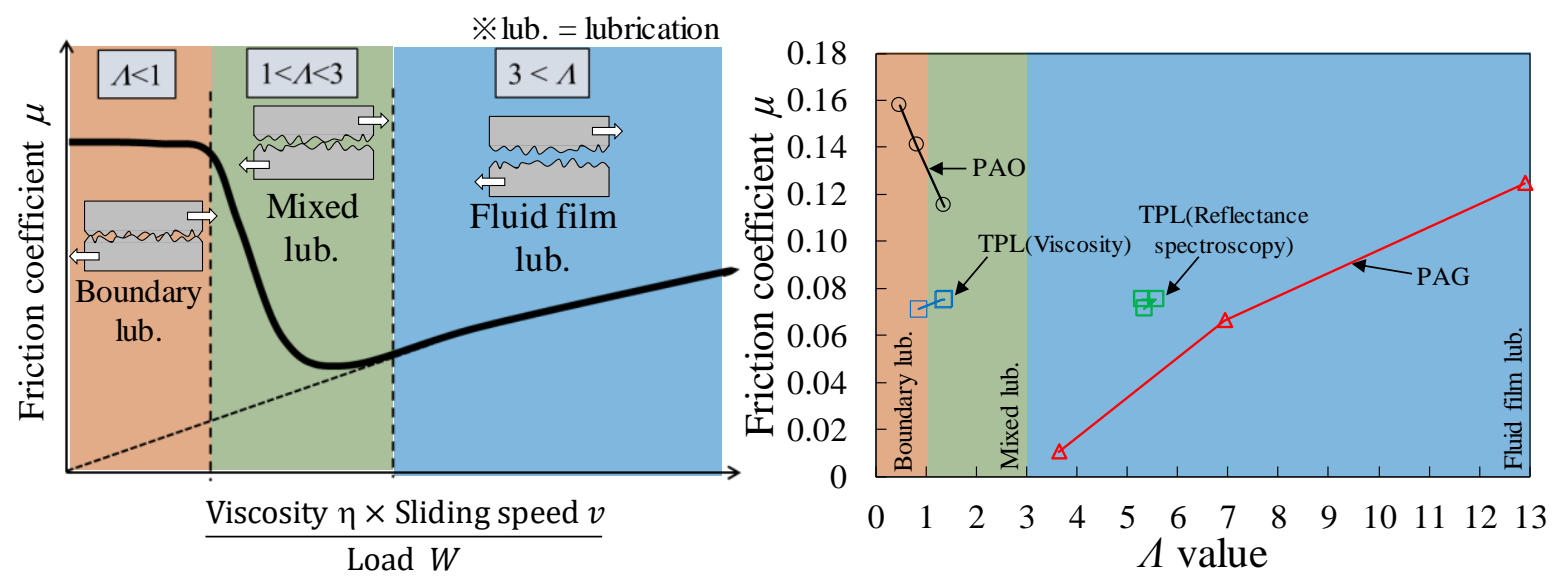

Fig. 18 The left figure shows the stribeck curve and a schematic diagram of the change in the lubrication state due to the $\Lambda$ value. The right figure shows the relation between the $\Lambda$ value and friction coefficient. The black plots are the values of PAO and the red plots are the one of PAG. The blue plots show the one of two phase lubricant with the $\Lambda$ value calculated from the viscosity, and the green plots show the one of two phase lubricant with the $\Lambda$ value calculated from the reflectance spectroscopy. 


\section{$5 \cdot 2$ 二液分離油のしゅう動部における油膜構造が油膜厚さに及ぼす影響}

図 16 に示したように温度が $30^{\circ} \mathrm{C}$ から $50^{\circ} \mathrm{C}$ に上昇した場合において, 油膜厚さが一定に保たれた考察を行う。 一般的に油膜厚さは粘度に依存する值であるため, 温度上昇に伴い油膜厚さは減少する. 害際に PAO 単体と PAG 単体の油膜厚さは温度上昇に伴い減少した。 そこで本実験で使用した二液分離油の場合は図 17 で示したように 高温において粘度が一定に保たれる傾向にあることが分かる．このことから，高温状態では使用した二液分離油

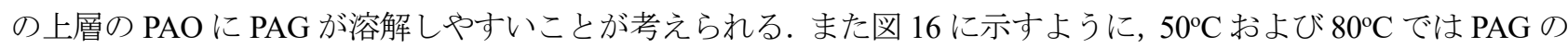
吸着膜層の厚さが増加していることからも，二液分離油の中の PAG の量が増加していることが分かる. 以上よ り，温度上昇により使用した二液分離油中に PAG が溶解しや寸くなることによって，より多くの PAG 分子が摩 擦面の SUJ2 およびサファイア半球表面に吸着し，油膜厚さを一定に保つことができたと考える.

また PAG の吸着層が存在している 3 層の光学モデルを立てる際に，油膜構造として PAG にのみ官能基がある ことから，選択的に摩擦表面に物理吸着寸るため摩擦面に存在していると考えている. そして，流動的になって いると考えられる中間層においては，低分子量の分子が摩擦面に侵入しや寸いことが考えられ，相対的に低分子 量の PAO が優位的に存在していると考えた（平田，1990）。また今回は各層が PAO および PAG に完全に分離し ているモデルを立てたが，一般的に完全に分離することはないと考えられ，実際には 1 層目と 3 層目では PAG が 主成分で少量の PAO が存在しており，2 層目ではPAO が主成分で PAG が少量存在しているモデルである可能性 が高い. そのためそのような光学モデルを用いて分析することにより精度の高い油膜分析が行える可能性がある. しかし，本実験で用いた PAO および PAG の光学定数が非常に近く，分析する際に現在の光学モデルより複雑に 光学モデルを設定することが困難であった．そのため，今後は光学定数の差の大きい試験油を用いることによっ て，複雑な光学モデルにおいても分析をする必要がある.

\section{6. 結}

本研究では，反射分光膜厚計を用いて摩擦面に形成された油膜をその場分析することにより二液分離油の油膜 構造および油膜厚さが摩擦特性に及ぼす影響を明らかにした。得られた主な結果を以下に示す。

1) しゅう動部における二液分離油の油膜は PAG の吸着層がしゅう動表面に形成されることによる多層となっ ていることが示唆された。

2 ) 反射分光膜厚計を用いたその場油膜分析の結果として，二液分離油を用いた際の摩擦実験における油膜は温 度が上昇しても油膜厚さが変化しないことが明らかとなった。

3 ）二液分離油はベース油単体である PAO と比較して実験温度内において 0.03 から 0.07 程度低い摩擦係数を示 し，また厚い油膜が形成されることが明らかとなった。

\section{文献}

Batchelor, A. W. and Stachowiak, G. W., Tribology in materials processing, Journal of Materials Processing Technology, Vol. 48, No. 1-4 (1995), pp.503-515.

Collins, R. W., An, I., Fujiwara, H., Lee, J., Lu, Y., Koh, J. and Rovira, P. I., Advances in multichannel spectroscopic ellipsometry, Thin Solid Films, Vol. 313-314 (1998), pp.18-32.

エンジン技術者教育協会 編, 初めて学ぶエンジン技術と機械工学, 理工学社 (2017).

Feynman, R. P. (坪井中二訳)，ファインマン物理学，岩波書店 (1968).

藤原裕之, 分光エリプソメトリ一, 丸善出版 (2011).

川口春馬，有機分散系の分散・凝集技術，CMC 出版 (2013).

平田昌邦, 潤滑油の粘度特性と粘度指数向上剂, 精密工学会誌, Vol. 56, No.7 (1990), pp.1216-1219.

広中清一郎，界面科学からみたトライボロジー，表面科学，Vol.12, No.6 (1991), pp.348-352.

Holmberg, K., Andersson, P. and Erdemir, A., Global energy consumption due to friction in passenger cars, Tribology International, Vol. 47 (2012), pp.221-234.

今村喜夫，高分子溶液の吸着，色材協会誌，Vol.38, No.12 (1965), pp.516-522.

Kamata, K., Kawamura, Y., Maruyama, R., Nagatomi, E. and Tazaki, H., The development to control simultaneously viscosity and separation temperature of a two phase lubricant for practical use, Tribology Online, Vol. 11, No. 1 (2016), pp.24-33. 
Koh, J., Lu, Y., Wronski, C. R., Kuang, Y. and Collins, R. W., Correlation of real time spectroellipsometry and atomic force microscopy measurements of surface roughness on amorphous semiconductor thin films, Applied Physics Letters, Vol. 69, No. 9 (1996), pp. 1297-1299.

好村滋行，マイクロエマルションの現象論，オレオサイエンス, Vol. 3, No. 10 (2003), pp.523-530.

古瀬和夫，ポリグリコール，潤滑, Vol. 32, No. 2 (1987), pp.95-99.

國枝博信，荒牧賢治，エマルションと HLB，オレオサイエンス, Vol. 1, No. 2 (2001), pp.179-186.

黒岩勝, 自動車用潤滑油と燃費節減, 日本機械学会誌, Vol. 83, No. 742 (1980), pp.1114-1120.

光永新二，ポリアルキレングリコール誘導体の特性について，日本化粧品技術者連合会会報, Vol.5 (1969), pp.4143.

村木正芳, 罒解トライボロジー摩擦の科学と潤滑技術, 日刊工業新聞社 (2007).

Nishimura, H., Umehara, N., Kousaka, H. and Deng, X., The clarification of low friction mechanism for hydrogenated amorphous carbon by in-situ observation of frictional area, Tribology Online, Vol. 11, No. 2 (2016), pp.341-347.

大原健司，梅原徳次，上坂裕之，野老山貴行，反射分光分析による油中摩擦における DLC 膜の構造変化層厚さ及 び微小摩耗量の評価方法の開発とその応用，日本機械学会東海支部第 62 期総会講演論文集(2013), ID:706.

坂手宣夫，自動車エンジン用トライボロジー材料技術の動向，まてりあ，Vol.53, No.12 (2014), pp.599-602.

鈴木四朗，近藤保，界面現象の科学，三共出版 (1996), pp.32-45.

渡嘉敷通秀，合成潤滑油，有機合成化学協会誌, Vol. 43, No. 7 (1985), pp.703-716.

Tung, S. C. and McMillan, M. L., Automotive tribology overview of current advances and challenges for the future, Tribology International, Vol. 37, No. 7 (2004), pp.517-536.

Wong, V. W. and Tung, S. C., Overview of automotive engine friction and reduction trends-Effects of surface, material, and lubricant-additive technologies, Friction, Vol. 4, No. 1 (2016), pp.1-28.

Wu, C. S., Klaus, E. E. and Duda, J. L., Development of a method for the prediction of pressure-viscosity coefficients of lubricating oils based on free-volume theory, Journal of tribology, Vol. 111, No. 1 (1989), pp.121-128.

山本雄二，兼田楨宏，トライボロジー，理工学社 (1998), pp. 113-125.

\section{References}

Batchelor, A. W. and Stachowiak, G. W., Tribology in materials processing, Journal of Materials Processing Technology, Vol. 48, No. 1-4 (1995), pp.503-515.

Collins, R. W., An, I., Fujiwara, H., Lee, J., Lu, Y., Koh, J. and Rovira, P. I., Advances in multichannel spectroscopic ellipsometry, Thin Solid Films, Vol. 313-314 (1998), pp.18-32.

Engine Technology Education Association, Engine technology and mechanical engineering for the first time learning. Rikogakusha Publishing Co. (2007) (in Japanese).

Feynman, R. P. (Tsuboi, C. trans.), The Feynman Lectures on Physics, Iwanami Shoten (1986) (in Japanese).

Fujiwara, H., Spectroscopic Ellipsometry, Maruzen Publishing (2011) (in Japanese).

Hirata, M., Viscosity characteristic of polymer thickened oils, Journal of Precision Engineering Society, Vol. 56, No.7 (1990), pp.1216-1219.

Hironaka, S., Kaimenkagakukaramitatoraiborozî, Surface chemistry, Vol.12, No.6 (1991), pp. 348-352 (in Japanese).

Holmberg, K., Andersson, P. and Erdemir, A., Global energy consumption due to friction in passenger cars, Tribology International, Vol.47 (2012), pp.221-234.

Imamura, Y., Adsorption of polymer solution, Journal of the Japan Society of Colour Material, Vol. 38, No. 12 (1965), pp. 516522 (in Japanese).

Kamata, K., Kawamura, Y., Maruyama, R., Nagatomi, E. and Tazaki, H., The development to control simultaneously viscosity and separation temperature of a two phase lubricant for practical use, Tribology Online, Vol. 11, No. 1 (2016), pp. 24-33.

Kawaguchi, H., Dispersion and Aggregation Technoloy for Organic Dispersions, CMC publishing (2013) (in Japanese).

Koh, J., Lu, Y., Wronski, C. R., Kuang, Y. and Collins, R. W., Correlation of real time spectroellipsometry and atomic force microscopy measurements of surface roughness on amorphous semiconductor thin films, Applied Physics Letters, Vol. 69, No. 9 (1996), pp. 1297-1299.

Komura, S., Phenomenological theories of microemulsions, Oleoscience, Vol. 3, No. 10 (2003), pp. 523-530 (in Japanese).

Kose, K., Polyglycol, Journal of Japan Society of Lubrication Engineers, Vol. 32, No. 2 (1987), pp.95-99 (in Japanese).

Kunieda, H. and Aramaki, K., Emulsion and HLB, Oleoscience, Vol. 1, No. 2 (2001), pp. 179-186 (in Japanese). 
Kuroiwa, M., Automotive lubricant and fuel economy saving, Journal of the Society of Mechanical Engineers, Vol. 83, No. 742 (1980), pp. 1114-1120 (in Japanese).

Mitsunaga, S., Characteristic properties of polyalkylene, Journal of Japan Cosmetic Chemists Association, Vol. 5 (1969), pp. 41-43.

Muraki, M., Science and lubrication technology of illustrated tribological friction, Nikkan Kogyo Shimbun, Ltd. (2007) (in Japanese).

Nishimura, H., Umehara, N., Kousaka, H. and Deng, X., The clarification of low friction mechanism for hydrogenated amorphous carbon by in-situ observation of frictional area, Tribology Online Vol.11, No.2 (2016), pp.341-347.

Ohara, K., Umehara, N., Kousaka, H. and Tokoroyama, T., Evaluation of the transformed layer thickness and wear depth of DLC coatings in oil using spectroscopic reflectometry, Proceedings of the 62th Conference of JSME Tokai Branch (2013), ID:706 (in Japanese).

Sakate, N., Trend of tribology material in automotive engines, Materia Japan, Vol. 12, No. 53 (2014), pp.10-13 (in Japanese).

Suzuki, S. and Kondou, T., Science of interface phenomena, Sankyo shuppan Co. (1996), pp.32-45 (in Japanese).

Tokashiki, M., Synthetic lubricating oil, Machine synthetic chemistry Association Journal, Vol. 43, No. 7 (1985), pp.703-716 (in Japanese).

Tung, S. C. and McMillan, M. L., Automotive tribology overview of current advances and challenges for the future, Tribology International, Vol. 37, No. 7 (2004), pp.517-536.

Wong, V. W. and Tung, S. C., Overview of automotive engine friction and reduction trends-Effects of surface, material, and lubricant-additive technologies, Friction, Vol. 4, No. 1 (2016), pp.1-28.

Wu, C. S., Klaus, E. E. and Duda, J. L., Development of a method for the prediction of pressure-viscosity coefficients of lubricating oils based on free-volume theory, Journal of tribology, Vol. 111, No. 1 (1989), pp.121-128.

Yamamoto, Y. and Kaneta, M., Tribology, Rikogakusha Publishing Co. (1998), pp.113-125 (in Japanese). 